


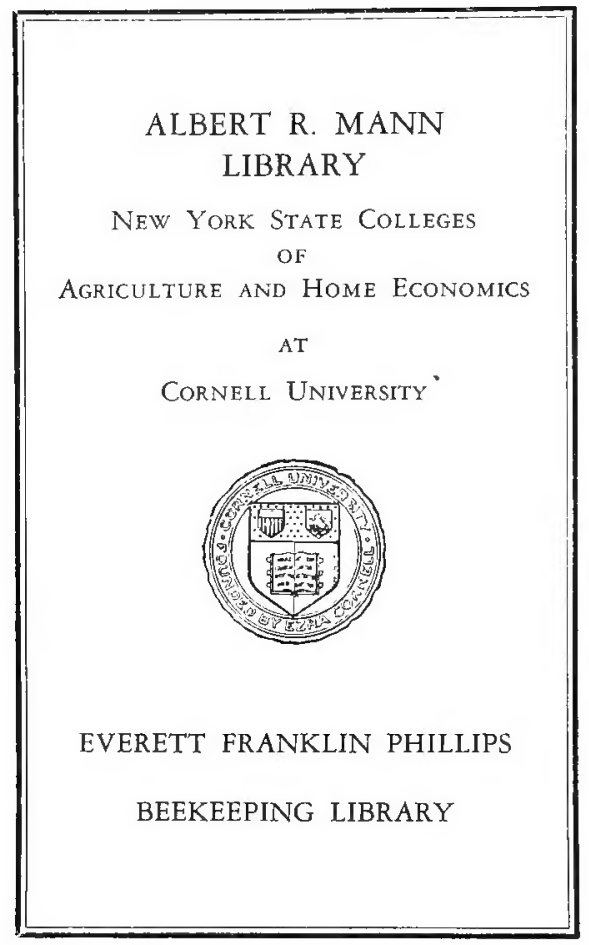




\section{The Successful}

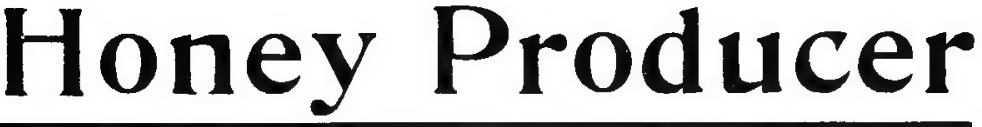

Concise Practical Information that will place the painstaking Bee-owner in the true groove for obtaining

\section{A Constant Income from Bees}

Honey Harvest lost through lack of Swarm Control;

Securing a Surplus in a poor Season;

How to avoid and Cure All Bee-diseases;

Absolutely Safe Wintering:

followed by Rapid development in Spring;

Why yields of 200-lbs. to 300-lbs. to the Colony are missed;

No hunting up Queen-cells;

The Only Scientific Method of Ventilating the Bee-hive;

The Curse of Candy-feeding in Winter;

Feeding that ensures Success;

The failure of graduated bottle feeders:

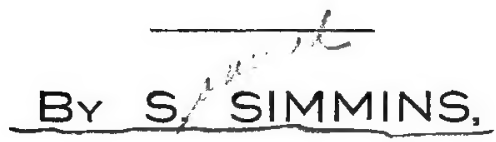

QUEENLAND - HEATHEIELD - SUSSEX. 


\section{THE SUCCESSFUL HONEY PRODUCER.}

Many bee-keepers fail to secure a surplus through allowing uncontrolled swarming; hiving the swarm separately ; often losing the swarm, or failing to make the best use of the summer increase of numbers.

Ninety-nine per cent. of bee-owners, including many so-called experts, lose vast quantities of honey that their bees would otherwise have stored had their energies and numbers been skilfully directed. Then they blame the weather for their own mismanagement.

\section{The First swarm}

should always be placed on the original stand, and the old combs with adhering bees mored to one side, or quite a fresh location, should a limited increase be required.

The swarm on the original site receives the supers after three days. and the moved lot losing so many adult bees, will not swarm again if treated as presently shown. The object being not to return the supers until the swarm has combs well on the way in the stock chamber, othersise pollen will he stored in the sections.

Correct Management makes queen-excluders unnecessary under the sulver's; they hinder the bees, restrict the output, and tend to induce swarming.

The use of excluder zinc between stock chambers, or under supers (unless working more than one queen), is only a confession of failure to produce better resilts withont it.

When the original combs are moved merely to one side, the two lots may be rennited when the young queen is laying; the old queen being removed three days before the nnion, and the supers replaced.

\section{Dividing better than Swarming.}

It is much better to divide in the first instance, as soon as the hive is crowded, rather than wait for the uncertainty of natural swarming, with the (freqnent) risk of the swarm-the vital force of the hiveflying away. There go the whole season's aims, hopes, and profit. 
The owner should never allow the risks of natural swarming, and lose control of the vital forces of honey prodnction that a good bee-colony offers.

There are thousands of such swarms allowed to stray away every sunmer, and theu the helpless owners, judging only by their depleted hires, think that bee-keeping does not pay.

\section{SWARMING WITHOUT INCREASE.}

Many years ago S. Simmins was challenged by a writer in the British Bee Journal to show how to aliow the equivalent of natural swarming, while at the same time retaining the full working force of the colony without permanent increase.

He had no difficulty in explaining his method of hiving the swarm on the old stand, and re-uniting with the young queen as soon as she became fertile. Mauy of Simmins' correspondents having since shown how they have secured large yields, even in poor seasons, by following this definite method.

\section{Treatment of Queen-cells after swarming or dixiding.}

After placing the natural Swarm on its original stand, it is desirable to wait seven days before destroying all queen-cells but one that may be on those combs moved away.

Otherwise remove all queen-cells (when capped) just before inserting a young fertile queen.

If dividing just before queen-cells are ready to be capped-always better thau allowing natural swarming-then it is better to wait nine days before removing the queen-cells. The very important point being that the starting of further queen-cells must be avoided. Others are certain to be developed if the queen-cells are remored too early.

\section{SWARMING \& DOUBLING WITHOUT INCREASE.}

While the former plan is essentially suitable for comb-honey production, allowing the re-united bees only one stock chamber, S. Simmins has offered the further plan of treating two stocks when working for extracted honey.

Two stocks standing near together are swarmed by moving one hive right away, about $11 \mathrm{a.m}$. on a warm morning. From the other hive at the same time remove all the combs with about half the quantity of bees, shaking the bees from alternate combs back with the queen, and place these combs above the other (moved) lot in an additional chamber. 
Fill up the denuded hive with frames of foundation, and add the extracting supers after three days, first transposing the outer frames of least worked foundation to the centre, which will expediate the process of completion and extension of the brood nest.

The doubled lot of brood cumbs will lose all the adult workers that return to the old site, and therefore will seldom require supers for a week or ten days.

\section{Renewing the Queens.}

If both lots have old queens, it is desirable after two or three days to make up two or three Nuclei by the side of the doubled lot moved to a new site. Or make up one with three combs of bees, eggs, capped and maturing brood, and when they have queen cells capped, divide into three with a cell to each. The three will allow for possible loss of one queen.

When laying, a yonng queen can be given to the doubled swarm and Stock, and the combs returned to the hive they came from. These queens, reared in early summer, by young bees only, will equal those reared by any more elaborate method. Queens purchased may save time.

The old queens may for greater safety be removed three days before giving the young ones; making sure that no queen cells, developed in the meantime, are allowed to mature after the exchange.

Nothing but the vast popalous colonies thus produced, will ever give yields approaching two or three hundred pounds to the colony.

\section{0-lbs. to 300-lbs. per Colony}

is not by any means an impossible attainment for the painstaking owner in an average season. Carefel Autumn preparation; the right class of Honey Bees; and the simple control of swarming - just where so many bee-owners get lost in a dense fog of mismanagement-will ensure that coveted surplus of hundred-weights of golden treasure to the colony.

\section{Hunting up Queen-cells}

once a week, as sometimes recommended, is a sadly crude, and needlessly laborious process--to call it nothing worse-that no practical bee-keeper should follow. Such methods are entirely avoided by Simmins' plans of "Swarming without Increase," and " Combiued Ioubling and Swarming without Increase; " scientific methods that he first offered to bee-keepers many years since as the only plans for securing immense, profitable 
colonies with no queen-cells to remore, but only the delightful tronble of removing hundred-weights of honey.

\section{AUTUMN FEEDING FOR SUCCESS. \\ Simmins' "Two-thirds Security" Method.}

Another important feature in management, that may decide all your future success, or the lack of it, is correct Autumu Feeding.

From mid August until mid-September, where no heather abounds, stocks must be fed slowly and constantly; then finished rapidly until the combs of the stock chamber are two-thirds filled, and at least twothirds of this store sealed over.

The slow feeding, with a vigorous young queen heading the colong, prodnces the young bees that are alosolutely necessary for successful wintering, and the rapid finish will finally restrict the queen to a smaller brood nest, that thereafter will slowly decline; while this method will ensure the proper sealing of the stores.

Dnring serere winter weather bees may quickly freeze to death when compelled to cluster between combs of unsealed stores, such as many correspondents often refer to when they have been using the

\section{Unreliable Graduated Bottle Feeders.}

In the Author's Apiary none of these out-of-date feeders are used; indeed they would be only a source of loss and waste of time where any number " of colonies are worked. Only rapid frame-feeders ensure satisfactory sealing of the stores in Autumm; while a medium framefeeder of all wood, used in spring is more satisfactory thau the bottle which latter is often then neglected if the weather is at all cool, while the small frame-feeder which is also a dummy, is warm and the bees are always ready to crowd into it.

\section{THE CURSE OF CANDY FEEDING.} Candy destroys hundreds of Colonies in Winter.

This, the lazy man's bee-feed, and the cause of hundreds of stocks dying out before Spring, shonld be condemned as the curse of beekeeping by every practical bee-owner.

Candy in winter is nothing but a "sop" to cover careless management. Hundreds of bee-owners fail to feed up with syrup in Autumn. "Oh? they will be all right," they say, "We can get plenty of candy." They forget that it costs four times as much and is little less than poison in the winter. We never use it except in the active Spring and Autumn 
Seasons, in connection with syrup, as a stimulant to breeding. Our methods of management and correct feeding in Autumn make Candy absolutely nnnecessil'y in winter when it is simply a disturbing element just at that period when bees should be perfectly restful in the sumilibernating state.

Candy will never save a stock where there is not a sufficiency of liquid food, properly stored, in the combs where the bees can reach it.

\section{SCIENTIFIC VENTILATION OF THE BEE-HIYE.}

In $1888 \mathrm{~s}$. Simmins offered the renowned Conqueror Hive as the first scientifice development in the correct ventilation of the modern bee-hive; but even to-day writers in the joumals are laboriously scribbling in the endeavour to find the best method (long since invented by S.S.), of ensuring perfect ventilation without draught through the bee-nest, as a great aid towards preventing bee-diseases.

As a matter of fact no other method can be found that allows this perfect ventilation, not only durng summer, but also in the coldest winter weather'.

\section{Many Bee-keepers are afraid}

of extra rentilation in winter, such as the Couqueror Hive offers, with the stock chamber not reaching the floor by a full half-inch at the least; or with it raised up as much as five or six inches!

They cannot realise the fact that a colony winters better with the stock chamber thus raised from the floor; but the atmosplere of the hive is actually drier and purer, therefore warmer and more healthy.

In the closer hive the poisonous gases are not readily carried off during the seison that the hees do not ventilate with their wings, hence the advantage of the Conqueror System which dispels the heavier impure air that deseculs to neitr the floor.

Moreover, the inside of the chamber walls do not reek with moisture as is the caste with strong colonies in common hives, and the outer mouldy comlss ire miknown in Simmins' scientifically constructed hive.

The final proof of correct construction is to be found in the fact that the hive eucourages enormous colonies for early spring work.

\section{OYERCOMING DISEASE.}

The readicst way to cure cases of I.O.W. disease in Common Hires is that of leaving off all quilting for a period, and when these must be used, they should not be too heavy or badly corroded with propolis, especially during the Autumn, when little breeding is going on, and the 
bees are becoming less active. All felt or enamelled cloths, or glass "quilts" should be avoided as a plaguc, where there in any danger from I.O.W. Entrances must be as wide as possible, according to the streugth of the colony.

\section{Camphor a great help.}

S.S. has frequently advised correspondents to place a cube of campbor on the floor of the hive where the Acarus is present; and in bad cases to spray over the tops of frames (and quilts before returuing) with spirits of camphor-three teaspoonfuls well shaken up in one pint of warm water.-This can be doue two or three times a week when the weather is mild. During winter leave a cube of camphor on the floor, and another over the first ticking.

\section{Feeding Rapidly in Autumn}

is a great aid towards a cure, as the vim and roaring energy caused thereby will help to expel disease germs before the bees settle down for winter. Affected stocks in hot weather, should-nay, wust-have their hives shaded.

\section{Foul Brood.}

When the I.O.W. complaint was devastating apiaries all over the country and the greatest experts (?) in the land were declaring positively that the disease was incurable and could only be extinguished by fire, S. Simmins stood alone in declaring that the trouble was quite a simple matter and was readily curable by correct manipulation, and the use of bees of a vigorous race.

Many of Simmins' clients have since been grateful for his advice, and following it, have been able to stagger so-called experts by the results attained; in many cases the simple insertion of "W.S." queens during the active season resulted in healthy, hurricane colonies.

Many years earlier S.S. declared that Foul Brood was easily curable, also without the use of medicines, except as a precaution against further infection.

In numerous cases, the insertion of a vigorons type of young queen, has resulted in a permanent cure. In other cases, the addition of an occasional comb of mature, hatching brood of the right strain of bees has acted in the same satisfactory manner.

It is nearly fifty years since S.S. first discovered and published this important fact, and twenty years later an American who had read the Author's book describing the same, offered this method of cure as his own idea! 


\section{Izal as a Preventative.}

The process of cure can be hastened, and risks of further infection checked loy the use of Tzal sprayed over and between the frames in the proportion of one teaspoonful to one quart of warm water. The quilt should also be siturated, and returned wet.

For feeding, use one teaspoonful to every 10-lb. of syrup, stirring in well when below $100^{\circ}$.

Badly affected combs can be remored and sprayed well over etch side, and returned one at a time to the centre of the brood nest, as the hees are able to corer and make use of them under careful stimulative feeding.

There is no disetase knozen lo bees but what an be readily checked, and carily curcd, ardere intelligent maniputation is brought to bear ufon the casc, and no diminuation of profit need ocint.

\section{SAFETY IN QUEEN INTRODUCTION.}

Be sure your stock is qneeuless before rushing in a new qneen ; then at a later date write to the breeder you purchased from saying he sent you a nseless qneen, when the fact was the genuine queen's fate was sealed from the momeut you inserted her.

This is no uncommon occurreuce where a queen is overlooked. Ner'ur forget that a fertile mother is rarely missing unless the bees have reared a virgin to supersede her, and it is useless to put in a raluable queen before such is found.

\section{The Only Definite Method}

is that of supplying the supposed queenless strok with a coml of unsealed brood, when after a day or two, the evidence as to queten vells being started, or otherwise, is a sure guide.

Don't forget that a virgin, if present, or queen cells if starten, must always be left until the same moment that you give the fertile gueen, when the bees will be in a naturally receptive condition.

\section{COMB HONEY PRODUCTION.}

In Simmins' pamphlet on "Prevention of Swarming," published some 40 years ago, he slowed how the usual surplus in sections may be donbled or trebled where the bee-keeper will take the trouble to get his section combs partly built before the actual honey glat occurs.

\section{Worked-out Section Combs.}

The foundation may be partly drawn out by "starting" full sheets of thin foundation in betreen the brood combs of a vigorous colouy. 
If put in one eveuing they may be removed the next, quite sufficiently started for the purpose required, if the stock is being fed, or a little honey is coming in. These drawn combs are then cut to size and inserted in sections in the usual way.

\section{Simmins' divided Section Holders}

allow the foundation to be drawn out as attached to one half of the holder; the second half being "clapped on" straight away without any cutting.

\section{With ordinary Section Crates}

the drawn combs are secured in adrance, by using candy over the sections together with a hot brick wrapped in flannel, and well-covered up. This should be exchanged for another hot brick (or hot-water bottle) every 12 hours and the crate removed and replaced by another as fast as ready.

\section{The adyantage of the Conquerer Hive}

in this connection is that the removed super need not be emptied of the bees, but placed at once under the stock, when the food, if any, stored there, will be removed, and be an extra stimulation in working out the new foundation in the next super added.

\section{Early and Strong Colonies.}

A colony that is going to produce hundred-weights of honey will be ready for this work early in April, giving ample time to prepare a large number of these drawn-ont combs ready for the honey flow, while the hot-water bottle may still be used with immense advantage over the supers at night, when the glut does arrive; the combs being filled and completed more rapidly, ensuring that the brood nest is not crowded with honey, thus leaving the queen ample room in her proper domain.

\section{A Triple Loss.}

Every pound of honey stored below the supers-early in the seasonmeans the loss of three times its reight in the supers: as it restricts the maintenance of a vast producing population, while the great quantity of pollen being brought in is also largely stored, instead of being used for brood-rearing, thus still further clogging the cells of the brood (?) combs.

\section{DRA WN SECTION COMBS FOR HEATHER HONEY.}

The Anthor has always insisted that for ensuring a vast increase in the Heather yield, drawn-out sections are of the utmost necessity, as 
many of his readers lave proved since he first introduced this definite metlod.

This does not mean that the bee-keeper should nse just those few sections he may have left unfinished from the earlier season, hut that the whole of his sections shall be prepared with drawn-out combs before he takes his bees to the moors.

\section{Young Queens only for Heather-work.}

Another equally important item the writer has always adrised is that no stock shonld be taken to the moors, with any hope of sucress, unless a desirable July-reared queen be inserted before the end of that month ; or a similar queen with a nucleus added at the end of July or the first week of August at the latest.

A queen of the previous season will always be an ntter failure at the moors, as she will uot attempt to produce sufficient young to keep up the cnormous population rejuired, and the reduced numbers simply crowd the hrood nest with what little heather honey they secure.

May or June queens of the same season will prove but little better, and should not be relied upon, as these will be taking their usual Autumu rest just when the utmost productiveness is required of them.

\section{Facts from a Heather District.}

If any proof were needed, a letter from a practical bee-keeper may he of interest. He secured from one White star Stock more heather honey in the disastrous seas m of 1924, aud more complete sections than the total of all other colonies in the neighbourhood.

"You will understand that I work for" as many drawn-out sections on the clover as I may require for the heather.... taking a leaf wht of your book on "Mamagement for Heather Honey'."

"I have never forgotten my old friend and tutor in my early lecekeeping lays, Mr. Ribbert Bell, of Hexhan. He wis the most surcussful bee-keepur in his day, and lo told me he attributer his success solely to folluwing your system, and breeding from mother lees he purchased from y'm."

\section{Foregone Conclusions.}

A "Tired " queen of the previous season, or a current season's early queen may give 20-1b. to 30-1b. of Heather Honey, whereas a selected quees reared and introduced to the stock in July is more likely to produce four to six times as much. 
Reducing the stock with a "tired" queen to six frames, or a pitiful shallow chamber, is a lame dodge, and a coufession of failure to realise the needs of this particular harvest-such attempts generally ending in a blank oue.

\section{Black Bees a failure.}

Black bees are condemned by the progressive bee-keeper. Some who still cling to them, notwithstanding their crushing failure to withstand the I. of Wight disease and foul brood, limit their watives to about six frames per stock for securing heather-honey; and yet say these bees are the best to use at the moors.

This plan simply proves the failure of that variety, as well as of their owners, to secure the best results. Nothing more certainly shows that natives are not sufficiently prolific, and that no stock which needs restricting to so few frames, will ever secure the highest results in heather-honey.

\section{Feeding Heavily}

before taking the stocks to the moors is another practice that must be condemned on several counts. The object is that the stock combs may be crowded with stores instead of brood, and the owner of stocks thus treated imagiues that the bees must therefore store the heather-honey in the supers.

Let us see how this plan works out. In the first place, the bees thus heavily fed by a process of "wear and tear" have just ended work on the earlier season's flowers, and a great many of them are not only adult but aged ; consequently the additional heary and needless storing results in the wearing out or ageing of many more of these hard-worked bees; a poor condition for starting once again at the heather on a third process of heavy storing, which as a matter of fact they do not undertake, for old bees, it should be understood, are not honey gatherers.

By all means see that the bees have a fair amount of food before the journey, but do not risk your reputation in sending to the moors stock combs crowded with syrup, a large proportion of which is certain to be stored in the sections with the heather-honey, if the weather is favourable for active work in the supers.

Only July-reared queens of a suitable variety, and the stock combs solid with brood at the beginning of Augnst, will save the tons of heather-honey that are usually wasted for want of correct application; while the stocks when bronght home will have enough youthful bees for safe wintering. 


\section{Simmins' Methods offer Success to YOU.}

Crude imitations of the Conqueror Hive have been offered, but these always result in distppointment, being simply unworkable, not being constructed according to the originator's dusign.

One correspondent says:- "The working of your Conqueror Hive compared with other hives in my apiary, is like driving a Rolls-Royce after a Ford."

Another writes:- "I have a great nımber of visitors; they are all struck with the Conqueror Hives, and some have offered une fabulous prices if I would sell. They see the buge masses of bees, and the combs chock full, without swarming. Even_- the manufacturer has stood astonished at the sight."

\section{Not a Dream, but Yerified Fact.}

In reference to these same methods and the working of the Conqueror Hive, a practical bee-keeper writes:-I had heard of your for years, but always thought of it as an "enthusiasts dream," until one day I visited an apiary and saw the Conqueror Hives filled to over. flowing with bees from your queens; then at a glance could. see that for the production of Honey, for ease with which the brood chambet could be examined when supers are on, etc., your system is A.1.

\section{Certain Income from Bees-Any year-Every year.}

"I am vely gratified with your "White Star" queens, and you definite system of Management: through adopting which I bave securec a heavy yield this season, whilst other local bee enthusiasts, with common queens and single chambers, have barely induced their bees $t$ enter shallow racks, and are denouncing the season as a poor one."

"My apiary has been visited by many bee-keepers, who state they have never previously seen sucb tiering of chambers. One stock ha: built up to 60 standard frames with a large population, and " the goods" are on hand in every hive."

"They all ask 'How is it done?' And I reply, 'By careful study o Simmins' Methods, and particularly with his 'White Star' pedigrea queens."-A.P.T. (North Wales).

N.B.-We do nothing in general hives and appliances, and offer the Conqueror Hive on early winter requests only; but if you wish to make one at horue, send us a stamped envelope, and we will send measurements with pleasure. 


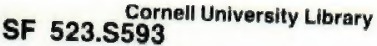

The successful honey producer, concise $\mathrm{p}$

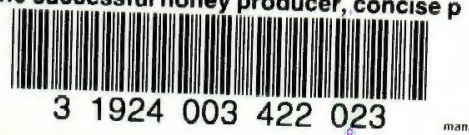




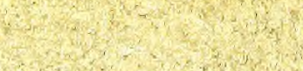

tors

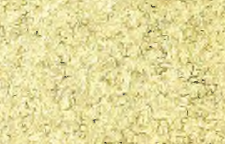

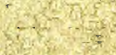
(120) C.t.7.

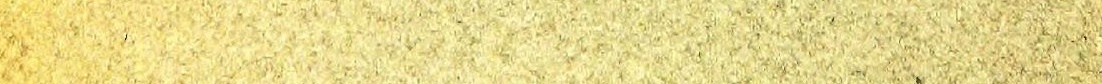
(3. 